\title{
Representative Bodies in Medieval Religious Orders: A Discarded Legacy?
}

\author{
Bert Roest

\section{Introduction}

The study of representation and representative bodies in later medieval and renaissance studies is frequently framed in a vocabulary of political thought and then more often than not connected with concepts in Roman and canon law and with the reception of Aristotle's Politics, and how the latter played out in the works of late medieval political theorists. ${ }^{1}$ Beyond this theoretical approach, most scholars who study medieval forms of representation "in practice" focus by and large on representation in "secular" political bodies, such as Spanish and Italian towns and communes, the Republic of Venice, and the emerging parliaments and estates general in larger territorial entities, such as England, Catalonia, Scotland, and the Low Countries.

It is less common for historians of political thought and later medieval parliamentary developments to integrate in these discussions the tradition of representative government in Europe's medieval religious orders, which often predated and continued to develop alongside representative developments in the secular world. This tradition within religious orders probably provided viable examples of efficacious representative procedures, and as such might have been of primordial importance for shaping late medieval concepts of political representation to begin with. This essay therefore tries to address this issue, by evaluating how scholars of medieval political thought and the origins of parliamentarism have ignored representative government in medieval orders, notwithstanding the availability of studies by specialists of order history, and by discussing the role of representative government in the Franciscan order, and its possible implications for the wider socio-political world in which the friars were active.

1 A standard treatment in this regard is provided in Quillet (1988). 


\section{Representation in Religious Orders within the History of Political Thought}

Within modern scholarship concerning the history of political representation, representative developments in religious orders normally do not figure prominently. Insofar as these developments are mentioned, they are signalled without analysing their properties or their possible consequences for the proliferation of representative institutions. A case in point is Arthur Monahan's Consent, Coercion, and Limit: The Medieval Origins of Parliamentary Democracy from 1986. This work devotes six pages to representative bodies within the Dominican order, charting in a not completely correct and coherent manner the role of elections and representation at the level of order provinces and at the level of the Dominican general chapter. Yet it does not come to terms with the possible revolutionary nature of this form of representative organisation. ${ }^{2}$

In fact, Monahan is more generous than most of his colleagues. In Wim Blockman's allegedly encompassing 1978 typology of representative institutions in late medieval Europe, religious institutions are conspicuously absent. ${ }^{3}$ Likewise, James M. Blythe's influential Ideal Government and the Mixed Constitution in the Middle Ages does not have much to say about the development of checks and balances and forms of representation in religious orders. It is fifteenth-century conciliarism that is portrayed as the ecclesiastical pendant to (proto-) parliamentary developments in the secular realm, and the focus is squarely on the legacy of classical legal and political concepts and their recasting by political thinkers from the mid-thirteenth century onwards, again in the wake of the reception of Aristotle's Politics.

This tendency is confirmed in more recent studies on medieval forms of representative government. It shows in Hwa-Yong Lee's popular Political Representation in the Later Middle Ages: Marsilius in Context from 2008. In its introductory chapter on the medieval understanding of political representation it succinctly refers to Gratian's Decretum in the context of episcopal elections, without displaying a profound understanding of the text in question, but it does not provide a proper analysis of the highly developed systems of election and representation in the medieval church and the religious orders, and does not ponder their possible long-term implications. ${ }^{4}$

Oakley's The Watershed of Modern Politics from 2015, which also focuses on the origin of political representation, devotes a full chapter to fifteenth-

2 Monahan (1987) 142-148.

3 Blockmans (1978).

4 Lee (2008) 39 . 
century conciliarism. It also alludes to developments in late medieval ecclesiology leading up to conciliarist positions in the context of the pope-emperor struggles of the fourteenth century, to outline some formative influences on "the emerging tradition of constitutionalism in the West," and the "process whereby the practices of representation and consent in the European kingdoms came gradually to be theorized." ${ }^{5}$ Oakley builds in that regard on the work of Brian Tierney, who probably has done most to put conciliar theory in the crosshairs of modern scholars of medieval political thought, ${ }^{6}$ and on the more recent studies of Anthony Black, which also interpret ecclesiastical constitutionalism and ecclesiological reflections on mixed government and representation first and foremost as the legacy of conciliarism. ${ }^{7}$ Yet this lip service to conciliarism notwithstanding, both in the works of Oakley and Black, and in a large number of other studies, the real move towards forms of representative government is nearly always connected with the nature of Europe's fragmented political landscape, the peculiar character of urban communal development, and the complex nature of late medieval state formation.

In slightly different terms, this is precisely the argument in the sweeping 2016 article on representation and consent by David Stasavage, which seems to be a sketchy preliminary study for a forthcoming monograph. For him the question concerning the rise of mechanisms of consent and representation in Western Europe, as opposed to the supposed failure of such mechanisms to evolve in Byzantium, imperial China, or the Islamic world, can be explained in terms of the emergence of "small and fragmented policies" after the decline of the Roman Empire in the West, "where it was feasible to organize representation and also desirable for rulers to do so."

Beyond attention to fifteenth-century conciliarism, references to the Decretum and other prominent canon law texts, and to the theoretical statements made by prominent medieval political theorists in the context of the struggles between papal and royal and/or imperial power that seem to prefigure full-blown conciliarist thought, most scholars of medieval political thought do not deal with the ubiquitous representative organs in other parts of the medieval church and especially within the religious orders. Nor do they analyse the electoral concepts and techniques developed within precisely these circles between the eleventh and the thirteenth century.

5 Oakley (2015) 210.

6 Tierney (1956; 1983); cf. Congar (1958) and Pennington (2004).

7 Black $(1979 ; 1992)$.

8 Stasavage (2016) 162. 
There are possibly good reasons for this apparent neglect. One that immediately comes to mind has to do with the fact that, for a variety of reasons, the writings of the most well-known medieval political theorists, including Thomas Aquinas, John of Paris, Aegidius Romanus, Marsilius of Padua, William of Ockham, and Bartolo of Sassoferrato, were prone to provide authoritative references to "universal" legal and philosophical principles, in line with scholastic modes of academic reasoning in which they had been trained. Intellectual historians, or rather historians of ideas following the great chain of high-brow political thought in the later middle ages all the way up to Machiavelli, will not quickly find in the works of these authors overt references to actual representative procedures in religious orders and the validity of such functioning systems in religious corporations to underpin their theoretical arguments. History of political thought in that sense frequently amounts to not much more than echoing the debates of academically trained medieval controversialists, quite a few of whom wrote in particular polemical contexts, and charting the way in which the protagonists in question developed philosophically convincing arguments based on uncontestable foundations of divine and natural law and fashionable (Aristotelian) notions of human nature, ethics, and politics. This tendency also has facilitated modern scholars to approach medieval representation predominantly as a secular political phenomenon, and even as part and parcel of the growth of later medieval secularism. ${ }^{9}$

\section{The Long-term Availability of Specialist Studies}

Nevertheless, the overall neglect of highly developed forms of representative government in Europe's medieval religious orders by most scholars of medieval political thought remains puzzling. After all, over the years several specialists of order history signaled the importance of this phenomenon and its possible impact on theories and especially on practices of representation in the late medieval secular world. As early as the late 1840 s, the French erudite Victor Leclerc pointed out the significance of 'general chapters' - ces grandes assemblées déliberantes - and election procedures in medieval religious orders, starting with the Cistercians, and called for studies on this phenomenon. ${ }^{10}$

$9 \quad$ One could argue that this is in part the legacy of John W. Allen and George de Lagarde. Cf. Allen (1923) and de Lagarde (1934-1963; 1937). Their works still seem to shape the research questions of most scholars of medieval political thought, either unconsciously or consciously, as in the case of Nederman (1995).

See, for instance, Leclerc (1849). 
The issue was dealt with more systematically with regard to the Dominican order in the 1913 monograph of Ernest Barker. This work outlines in considerable detail the emergence of representative assemblies and the election of offices within the order, and tries to reconstruct the influences behind these developments. It makes a case for the inspiration and influence of these mechanisms in the Dominican order on comparable mechanisms introduced in thirteenth-century English episcopal synodal procedures under the friar-Archbishops Robert Kilwardby (a Dominican) and John Pecham (a Franciscan), as well as on assemblies called for by the English kings, and on the emergence of specific mechanisms of representative convocation that came to define the English parliamentary system from the late thirteenth century onwards. ${ }^{11}$

For whatever reason, Barker's work never made much of an impact. During the following decades, the issue of representative bodies in religious institutions was only raised in passing, without much elaboration, most often in the context of studying majority principles in political assemblies. ${ }^{12}$ Yet in the 1950s, the Belgian sociologist-historian Leo Moulin devoted at least three seminal articles to the government of religious communities and their representational aspects. He argued for the primacy of religious institutions in developing forms of representative government and modern techniques of voting and majority formation. Starting from the view that matters of representation and consent built on very old principles within the early church, and as such were codified in twelfth-century canon law, Moulin distinguished a quick development in representative government and election procedures during and after the twelfth century, first in the Cistercian order, and subsequently in orders of regular canons, Benedictine congregations, the Carthusians, and in the budding mendicant orders, concomitant with the adoption of provincial and general chapters with legislative powers. This went hand in hand with an increase in canon law regulations concerning chapter representation and election procedures in religious corporations, all of which were codified in decrees issued by the third and fourth Lateran Councils (held in 1179 and 1215 respectively). ${ }^{13}$

Much later, in 1983, Moulin once more addressed the issue, but now from a different angle, suggesting that Marsilius of Padua's famous Defensor pacis (1324), which figures prominently in many studies on the development of late

Barker (1913). Not all of Barker's inferences and interpretations have withstood the test of time, of course. The main importance of this work was its emphasis not to isolate church and state, but to recognise that the development of representation in church and state developed side by side and that there was considerable interaction between the two realms in this development.

12 See the dispersed remarks in Stawski (1920) and in Avondo (1927).

13 Moulin $(1951 ; 1952 ; 1953)$. 
medieval political thought, was indeed inspired by systems of representation and governmental organisation in Europe's main religious orders. This would have been visible in Marsilius's depiction of the universitas civium and its powers, in his depiction of the principles of potestas delegata, and also in his treatment of election procedures and qualified majority principles. Due to his own conflicts with the papacy at the time, Moulin argued, Marsilius would never have openly acknowledged this debt, and it is clear that most modern scholars have never looked in this direction, trying instead to establish with limited success how Marsilius's system compares to the theories outlined in the Politics of Aristotle. ${ }^{14}$

The question is not so much as to whether Moulin is right, but that, just like the interpretation put forward in the older work of Barker, Moulin's call to take representative bodies in religious orders seriously hardly seems to have registered among later scholars of medieval political thought. It is probably not a coincidence that the previously-mentioned monograph of Hwa-Yong Lee on the historical context of the Defensor pacis from 2008 does not broach this possibility, not even to deny it, and that the author, if his bibliographical references are any indication, is largely unaware of this angle of scholarship, which as late as 1979 had seen a significant additional contribution. In that year, the French law historian Jean Gaudemet issued with three colleagues a booklength study on the development of election procedures and representative systems within all types of medieval religious institutions and at different levels of the ecclesiastical hierarchy. One is hard put to find this work in bibliographies of subsequent publications on medieval political thought that in one way or another deal with medieval concepts of representation. ${ }^{15}$

Due to peculiar cultural divisions in both the world of medieval studies and in the sub-fields of history of political thought and parliament studies, the suggestions of Barker, Moulin, Gaudemet, and others have not made much of an impact beyond specialists in the history of medieval religious orders and their institutional setup. Aside from the monograph of Arthur Monahan mentioned earlier, which pays lipservice to Moulin's articles from the 1950s, most specialists of medieval political thought and political organisations do not deal at length with religious orders as age-old multinational playing grounds for functioning systems of representation in their own discussions of participation of stakeholders within various types of corporate government. As said before, only in the context of the early fourteenth-century conflict between pope and emperor - the background against which scholars normally discuss political

\footnotetext{
14 Moulin (1983).

15 Gaudemet (1979).
} 
representation in the works of Ockham, Marsilius of Padua, and others - and in the context of the fifteenth-century conciliar movement do they include the church and the general council in their discussion of political representation.

Since the later 1990s a group of predominantly French and Italian scholars has asked attention for the compatibility between the Franciscan project of evangelical pacification of society and the unfolding commercial urban body politics in Italy and Catalonia. Counter to much earlier research, which saw an intrinsic discrepancy between the Franciscan ideals of poverty and the protocapitalist transformation of urban society, these scholars have pointed out that the friars were willing to accept the dynamics of the market economy and the entrepreneurial spirit of urban merchants, as long as acquired wealth and economic power could be made to benefit the bonum commune. In the course of time, as has been argued in particular by Giacomo Todeschini, Paolo Evangelisti, and their disciples, this enabled Franciscan friars to develop encompassing visions of urban and territorial socio-economic and political development within overarching evangelical parameters, geared towards the realisation of an economically and politically flourishing civitas christiana. ${ }^{16}$ But even in this rather innovative type of scholarship, issues of representation and related topics concerning corporate government structures advocated by Franciscan spokesmen such as Francesc Eiximenis (d. 1409) and fifteenth-century Italian Observant friars are to my knowledge not analysed in depth. It remains somewhat of a blind spot within historical research on medieval political thought. ${ }^{17}$

Questions of influence aside, the emergence of representative bodies within Europe's major religious orders from at least the twelfth century onwards in and of itself provides more than sufficient grounds to incorporate it in the history of medieval political thought. After all, we are talking about huge and rather powerful multinational corporations that played a variety of roles within medieval society. That alone should suffice to include the study of medieval religious orders in discussions on the rise of representative bodies and the

16 See, for example, Todeschini (2008); Evangelisti (1996; 2006); Cacciotti and Melli (2011).

17 Beyond this, most scholars interested in Franciscan or more general mendicant political theory are either interested in the ecclesiological consequences of Franciscan concepts of evangelical poverty, which Ockham exploited to deny the church the right to exercise power over secular affairs, or in the way concepts of natural law and Aristotle's Ethics and Politics shaped mendicant mirrors of princes and scholastic treatises on royal and papal power. Alongside of additional contributions within the tradition of Todeschini and Evangelisi, these are central themes in several contributions to the volumes Etica e politica: Le teorie dei frati mendicanti nel due e trecento. Atti del XXVI Convegno internazionale, Assisi, 15-17 ottobre 1998, Atti dei Convegni della Società internazionale di studi francescani e del Centro interuniversitario di studi francescani, Nuova serie, 9 (Spoleto: Centro Italiano di studi sull'alto medioevo, 1999), and Musco (2007). 
technical apparatus that facilitated its fruition. Luckily, thanks to much recent scholarly investment in the institutional setup of medieval religious institutions across the board, it is now much easier than before to access details on the representative systems developed in various orders. ${ }^{18}$

\section{Mechanisms of Political Representation in the Franciscan Order}

I would like to exemplify this with a short analysis of government structures within the Franciscan order, or the order of friars Minor, which in its set-up followed both Cistercian and Dominican examples, ${ }^{19}$ and which, as the research of Todeschini cum suis indicates, is increasingly being scrutinised for its importance in late medieval socio-economic and political life. The Franciscan order has as added relevance its relative size and impressive geographical distribution. Established as a canonically recognised order by 1209 or thereabouts, it quickly became the largest mendicant order by far. By the early 1330 it had more than 1376 convents, divided over 34 European order provinces and a number of additional vicariates in European border regions and far beyond, with missionary stations as far away as Central Asia and Mongol China. ${ }^{20}$

Whereas Dominicans quickly fleshed out a streamlined and hierarchical system of representation between 1216 and the 1230s, in line with the latest canonical guidelines, but with a deliberately more democratic streak than the representative systems in the Cistercian order and within most orders of regular canons, the early Franciscans came to a comparable setup somewhat reluctantly. At first, the order was subject to the overwhelming charismatic authority of Francis of Assisi, and at the same time seemed to have coveted ideas of a divinely inspired form of direct democracy. ${ }^{21}$ This was part and parcel of the original utopian vision of the functioning of the Franciscan fraternity. It was conceived as a fully evangelical community where all could live the perfect imitation of Christ on Earth without hierarchies and distinction between

18 See for instance Hoffmann (2000); Cygler (2001); Waddell (2002); Freeman, (2002); Andenna and Melville (2005); Cygler (2007); Sykes (2008); Cygler (2009); Grélois (2016).

19 On the Cistercians, see several studies mentioned in the previous note. On the Dominicans, see aside from Barker also Galbraith (1925), Cygler (2014), as well as the in-depth articles of Tugwell: "The evolution of dominican structures of government", Archivum Fratrum Praedicatorum 69 (1999), 5-60; 70 (2000), 111-242; 71 (2001), 5-182; 72 (2002), 26-159; 75 (2005), 29-79, which provide much additional nuances, especially with regard to the way Dominican general chapters and provincial chapters held the "executive branch" of order government to account.

$20 \quad$ Golubovich (1913); Moorman (1983); Eubel (1892).

21 Desbonnets (1986). 
members. Those in charge were nothing more than ministers, that is to say the servants of those they were guiding. Whatever the subsequent stages in order development, that name with its biblical connotations was to stay. In contrast with the nomenclature we find in other orders, the Franciscan order would continue to have ministers, guardians, and custodians, not priors, abbots, superiors, or magisters general. ${ }^{22}$

This initial vision also meant that in principle all friars were to take part in the deliberations during the annual general chapter meetings at Assisi. The rapid numerical and geographical expansion of the order after its first papal recognition in 1209 ensured that this situation soon became untenable. This became clear at the famous general chapter delle stuoie, held around 1220, in which according to some sources no less than 5000 friars would have taken part. ${ }^{23}$ Two or three years prior to that event, a first structure of order provinces and custodies emerged, to streamline communication and the efficacious deployment of friars in the quickly growing order. Yet at that juncture the Franciscan order did not even have a properly recognised rule, nor proper procedures for decision making and internal appointments.

The Franciscan rule of 1221 and the papally approved Franciscan rule of 1223 circumscribe to some extent the functions of guardians (in charge of an individual convent), custodians (administrators of custodies, or sub-provincial networks of friaries), provincial ministers (administrators of individual order provinces), and the minister general of the order, but they are not strong in details. They provide some information about the convocation and the participants of provincial and general chapters (probably also to curb the number of friars present). Moreover, the rule of 1223 does indicate that at the general chapter the collected custodians and provincial ministers together were to choose and in principle also could depose the minister general. These texts remain silent about the length of tenure of the minister general, or about the question how the custodians and provincial ministers were selected. In practice, Francis of Assisi and his immediate successors as minister general

22 Cf. Dalarun (1999) 34-38, 48-49. While working on this essay, I came across yet another, more recent work by Jacques Dalarun, which from a slightly different angle makes a case for looking at monastic and mendicant forms of government as an inspiration for thinking about democracy. Instead of focusing on issues and technicalities of representation, it proposes first and foremost a perusal of monastic and mendicant concepts of service (ministerium) in the context of community and order government, thus to provide an alternative vision on leadership and the exercise of power. See: Dalarun (2012).

23 Legenda Perusina seu Compilatio Assisiensis, in E. Menestò and S. Brufani (eds.), Fontes franciscani, Testi, 2 (Assisi, 1995), 1471-169o, no. 114.; cf. Desbonnets (1986) 9. 
frequently appointed provincial ministers to their liking, and this could undermine the chapter's control over the order's executive branch.

Shortly before his death in 1226, Francis had issued a testament, which tried to fixate the interpretation of the rule for once and for all. It soon became apparent that this blocked constitutional developments, and in 1230 the Franciscan general chapter decided to appeal to Pope Gregory IX. The resulting bull Quo elongati not only denied the legal validity of Francis's testament but also established that from henceforth each order province should dispatch to the order's general chapter its provincial minister, as well as one custodian, to be selected by all custodians from the province. From this moment onwards, a clear principle of representation guided the makeup of the Franciscan general chapter. ${ }^{24}$ Yet the convocation of the general chapter remained at the whim of the minister general. Hence the young order retained an authoritarian streak that distinguished it from its Dominican counterpart.

This would change, however, in response to ongoing expansion and continuing unrest under minister generals Giovanni Parenti (1227-1232) and especially Elias of Cortona (1232-1239). The latter was accused of authoritarian behavior, especially for his appointment of provincial ministers and officials empowered to perform visitations of individual provinces and friaries, and for his refusal to convoke a general chapter. He was deposed in 1239 in an extraordinary general chapter meeting called for by his opponents, who had obtained the backing of Pope Gregory IX. These events more or less forced the order to take its institutionalisation seriously. This led to a body of legislation in and after 1239, all of which was streamlined in the so-called Narbonne Constitutions from 126o, and their revision during the general chapters of Assisi (1279) and Paris (1292). ${ }^{25}$

24 Quo elongati, in: Bullarium Franciscanum I, 70 (no. 56). See also Gregory IX, "Die Bulle 'Quo elongati' Papst Gregors IX," H. Grundmann (ed.), Archivum Franciscanum Historicum 54 (1961), 20-25.

25 The statutes of Narbonne, Assisi and Paris received their first critical and synoptic edition as Statuta Generalis Ordinis edita in Capitulis Generalibus celebratis Narbonae an. 1260, Assisii an. 1279 atque Parisiis an. 1292 (Editio critica et synoptica), ed. M. Bihl, Archivum Franciscanum Historicum 34 (1941), 13-94; 284-358. They, as well as the constitutions of 1239, and fragments of intermediate texts are now also accessible in Cenci and Mailleux (2007). For a long time, historians thought that none of the constitutions prior to 1260 had survived, and some scholars assumed that the 1260 Narbonne constitutions were in fact the oldest ones ever made. This was disproven for once and for all when Cesare Cenci discovered fragments of the 1239 constitutions and compared them with the Narbonne text in De fratrum Minorum Constitutionibus Praenarbonensibus, ed. C. Cenci, Archivum Fratrum Historicum 83 (1990), 50-95. The following paragraphs are based on my reading of the Constitutiones praenarbonenses in: Cenci and Mailleux (2007) 69-75, and the secondary literature listed in note 26 . 
These documents reveal that a more balanced hierarchical system of order administration came into being, which gave due attention to the frequency of provincial and general chapter meetings, the way in which representatives for these bodies were chosen, the procedures concerning which matters were first to be discussed and approved at the provincial level prior to forwarding them to the general chapter, the transfer of authority by these bodies onto the executive officials on the provincial and the general levels for specific time periods, and the way in which these officials were held to account. This went hand in hand with the creation of formal procedures to codify and distribute decisions of the provincial and general chapters.

From 1239 onwards, general chapters were to be held every three years, and the representatives consisted of the body of provincial ministers from all Franciscan order provinces, with in addition from each order province one custodian elected by the custodians from the province in question, as well as a frater discretus representing all other friars within each province. This frater discretus, the representative of the rank and file, was elected by friars from the province (or by their representatives sent from individual friaries) during the preceding provincial chapter meeting. At the general chapter, which after 1239 on average would have consisted of circa 140 persons, a number of definitori was elected from the gathered fratri discreti and provincial ministers. This separately selected group was made responsible for the management of the general chapter itself. It was also supposed to gather and read the sealed missives and requests from provincial chapters and individual houses brought toward the general chapter, and to help prepare the text of the general chapter decisions.

Each triennial general chapter was to begin on the day of Pentecost, the day that commemorated the apostles' infusion with the Holy Spirit. The first act of the chapter was to judge the performance of the existing minister general. He was to ask forgiveness for his mistakes and leave the convocation hall, after which the gathered provincial ministers and custodians, assisted by the definitori, evaluated the performance of the minister general since the previous general chapter, taking into account the comments and complaints sent in by individual provinces and religious houses. Following this evaluation, a subsequent vote by the attending provincial ministers and custodians determined the fate of the minister general by absolute majority. This could mean the deposition of the minister general, and in that case his successor was to be elected the next day. When the provincial ministers and custodians eligible to vote on this matter did not succeed to choose a candidate by majority vote, the decision was handed over to a committee of three or five wise friars, who could act on behalf of everybody. 
Once the vote concerning the minister general had passed, the general chapter - the provincial ministers and the fratri discreti, minus the custodians - began discussing the dossiers and wishes brought forward from the various provincial chapters, as well as the assignment of students and lectors to the order's studia generalia, and the appointment of important public preachers with license to preach in one or more order provinces. The general chapter also appointed visitatores to check on the religious life and rule observance within each order province, it made decisions concerning the dispatch of missions apud infideles, the creation of new order provinces and related matters, ending with deciding upon the venue for the next general chapter meeting.

At the provincial level a provincial chapter was to be held each year. This chapter was in principle open to the custodians of the provincial custodies and all friars of the province in question, although it was from nearly the outset rather common for friaries to send only a few representatives. Each friary in the province had one vote in the assembly, to be voiced by a frater discretus deputised for that task by his respective community. At the provincial chapter a body of four definitori was elected, with a spare one in case of a tied vote, which was to evaluate the performance of the sitting provincial minister, and which together with him was responsible for determining the chapter's agenda and the organisation of its orderly proceeding. Following the evaluation of the provincial minister's performance, the provincial chapter voted on the appointment and dismissal of the provincial minister, with voting rights given to the custodians of the individual custodies and to the fratri discreti sent by the friaries of the province. In the same way the provincial chapter decided on the designation of custodians (something that later reverted back to the discretion of the provincial minister), the appointment of convent lectors, the assignment of students within provincial and custodial schools, and discussed topics brought forward in writing by the representatives of individual friaries. The provincial chapter came to decisions by majority vote, and only those matters that had been discussed and decided upon with a majority vote in the provincial chapter were to be submitted in sealed documents to the upcoming general chapter. ${ }^{26}$

This basic structure of representative government, pushed through at the general chapter of 1239, met with some resistance and would undergo several emendations in the course of the thirteenth century, which on average tend to reinforce the executive power of the provincial ministers and the minister

26 See on all this also the analyses in Mapelli (2003) 21-24; Barone (1999) 87-98; Dalarun (1999) 73-102; Etzi, (2005) 36-74. Among the older studies, still valuable are Neukirchen (1952) and Brooke (1959). 
general. Yet none of the major legislative texts accepted at important general chapter meetings, including those of Narbonne (1260), Assisi (1279), and Paris (1292), undermined the central tenets of the representative elements and the priority attached to the legislative power of the general chapter. These texts also detailed voting procedures for provincial and general chapters, which followed in principle the instructions put forward in canon 24 of the Fourth Lateran Council. Both in line with these instructions, and on the basis of practical experience, the constitutions of Narbonne and later installments likewise included additional procedures in case of the sudden death of provincial ministers or the minister general, and in case of other extraordinary circumstances, such as the forced abdication of order superiors due to heresy. In this way, the whole representative system was able to cope with specific crisis situations. ${ }^{27}$

\section{Possible Repercussions of Representative Practices in Religious Orders}

Hence, like their colleagues in other major religious orders, all clerical friars active within the Franciscan order from the late 1230s onwards, would have become thoroughly acculturated by the practices of representation, deliberation, and voting in their order's provincial and general chapter meetings. Many of these friars would go out in the world, to act as public preachers, to perform as counsellors of rulers and city councils. A significant number of them would also end up in high ecclesiastical positions as bishops, archbishops, and the like, and as such presided over provincial synods and acted as personal advisors to kings. A case in point is Archbishop John Pecham in England, who figures alongside of his Dominican predecessor Robert Kilwardby in the aforementioned study of Barker. It has also been documented that from early on mendicant friars acted as arbiters and guarantors within Italian, Spanish, French, and Flemish communes during all kinds of legal and economic transactions, and were used by these communes as impartial officials to oversee and confirm local elections, just as their friaries were used as communal meeting points for urban council meetings, and as archival depositories for important communal documents and guild statutes. ${ }^{28}$ In this context it should also be noted that quite a few Franciscan friars (like some of their Dominican

27 Cf. Mapelli (2003) 29-34.

28 For an initial overview of the activities of Franciscan (and other mendicant) friars as peace brokers in and between communes, as election officers, and as communal embassadors, see da Campagnola (1999) 65-118; Artifoni (1995) 163-164; Bartoli Langeli (1985) 91-99; Vauchez, (1966). 
counterparts) were directly involved with drawing up new communal statutes. This phenomenon, which already started early in the order's history, surged during the fifteenth century, when Franciscan Observant preachers were asked to draw up a number of governing statutes for towns such as Perugia (1425), Terni (1444), and Trevi (1487). ${ }^{29}$

Considering the embeddedness of the mendicant friars in the urban landscape and their presence at European courts, the question can be asked whether their intra-order government experience would have been brought to bear on the way in which they acted as preachers, counsellors, and even co-legislators between the thirteenth and the late fifteenth century. It is not easy to answer this question. Jacques Dalarun, who in 1999 issued an influential study on the issue of power in the Franciscan order during the thirteenth century, has been inclined to answer negatively: according to him there is not much evidence to support the thesis that the friars actively tried to export directly aspects of their own stratified representative system to communes for which they acted as counsellors or even as co-legislators. ${ }^{30}$

Dalarun's interpretation might be correct in so far as friars normally did not impose their representative systems on the communities for which they acted in some kind of legislative capacity. Yet this verdict needs careful verification, with attention to more technical aspects, as the friars did apply their expertise with regard to voting procedures, codification, and confirmation practices when they acted on behalf of communes, and the fact alone that they were asked in these capacities might indicate the acknowledged expertise of the mendicants in such matters. Moreover, as both Dalarun and Barone have signalled with recourse to the Franciscan friar Salimbene of Parma, the mendicants were often proud of their representative structures, judging them to be superior to some of the more fledging communal structures they encountered in the secular realm. ${ }^{31}$

It might not have been a coincidence that Franciscan friars, as well as their Dominican and Augustinian colleagues, produced texts of political theory that habitually discussed matters of sovereignty, delegation, and representation. After all, Thomas Aquinas, William of Ockham, John of Paris, and Bonagratia of Bergamo, to name but a few, were all mendicant friars. As explained, many of their texts were produced in specific polemical contexts. At the same time, these academically trained authors expounded their arguments on ideal forms

29 See aside from the studies mentioned in the previous note also Bonmann (1965) and Evangelisti (2013).

$30 \quad$ Dalarun (1999) 131-134.

31 Barone (1999) 59, 68-70; Dalarun (1999) 131-132. With reference to Salimbene of Parma, Cronica, ed. G. Scalia, 2 vols. (Bari: Laterza, 1966) I, 230. 
of government, or their expositions for or against the plenitudo potestatis of pope or king/emperor in universalist terms. Historians of political thought have not considered as to whether underlying implicit assumptions in these texts might have been informed by a thorough familiarity with modes of representation and delegation within their own religious life. It might be worthwhile to re-investigate some of these texts from this specific angle.

Likewise, scholars who, in the wake of the ground-breaking work of Todeschini and Lambertini, focus on the Franciscans as strong proponents of a program of religious, social, and economic pacification of Christian society that even allowed for the development of economically flourishing urban communities within strict evangelical parameters, might also want to include this perspective in their discussions. After all, Franciscan experiences of order government might have impacted their vision of the ideal organisation of the communes and the larger realms in which they were active. Only a thorough re-reading of the available sources will bear this out.

Finally, the very example of the government organisation of large religious orders, such as the Cistercians, the Carthusians, various orders of regular canons, the Dominicans, and the Franciscans, might have influenced outsiders. The enduring representative elements present in these multinational entities provided ample evidence for the feasibility of representative processes and carefully imposed checks and balances between legislative and executive levels of corporate government. Outsiders must have noticed the institutional strength these orders were able to display in the face of changing historical circumstances, and that much of this strength was bound up with the way in which these orders had organised their internal government structures. That alone might have been an incentive to emulate some of their most successful practices, overtly or in silence.

Whatever the actual influence of representative bodies within religious orders on the secular world, it is a mistake to ignore them when discussing the emergence of representative institutions during the medieval period. The mere size and omnipresence of these orders, as well as their stature as nearindependent international organisations make that an untenable option.

\section{Bibliography}

Allen, J.W., "Marsiglio of Padua and Medieval Secularism," in F.J.C. Hearnshaw (ed.), The Social and Political Ideas of Some Great Medieval Thinkers (London, 1923), 167-191. 
Andenna, C. and G. Melville (eds.), Regulae-Consuetudines-Statuta. Studi sulle fonti normative degli ordini religiosi nei secoli centrali del Medioevo (Münster, 2005).

Artifoni, E., "Gli uomini dell'assemblea. L'oratoria civile, i concionatori e i predicatori nella società communale," in La predicazione dei frati dalla metà del '20o alla fine del '30o. Atti del XXII convegno internazionale, Assisi, 13-15 ottobre 1994 (Spoleto, 1995), 143-188.

Avondo, E.R., I sistemi di deliberazione collettiva nel medioevo italiano (Turin, 1927).

Barker, E., The Dominican Order and Convocation. A Study of the Growth of Representation in the Church during the Thirteenth Century (Oxford, 1913).

Barone, G., Da frate Elia agli Spirituali (Milan,1999).

Bartoli Langeli, A., "Comuni e frati minori," in Il francescanesimo nell'Umbria meridionale nei secoli XIII-XIV. Atti del V convegno di studio, Narni-Amelia-Alviano, 23-25 maggio 1982 (Narni, 1985), 91-99.

Black, A., Council and Commune: The Conciliar Movement and the Fifteenth Century Heritage (London, 1979).

Black, A., Political Thought in Europe, 1250-1450 (Cambridge, Eng., 1992).

Blockmans, W., "A Typology of Representative Institutions in Late Medieval Europe," in Journal of Medieval History 4 (1978), 189-215.

Bonmann, O., "Problemi critici riguardo ai cosidetti 'Statuta Bernardiniana' di Perugia (1425-1426)," in Studi Francescani 42 (1965), 278-302.

Brooke, R.B., Early Franciscan Government. From Elias to Bonaventure (Cambridge, Eng., 1959).

Cacciotti, A. and M. Melli (eds.), I francescani e l'uso del denaro: atti dell'viII Convegno storico di Greccio, Greccio, 7-8 maggio 2010 (Milan, 2011).

Campagnola, S. da, Francesco e francescanesimo nella società dei secoli XIII-XIV (Assisi, 1999).

Cenci C. and R.G. Mailleux (eds.), Constitutiones Generales Ordinis Fratrum Minorum, I (Saeculum XIII), Analecta Franciscana XIII, Nova Series Documenta et Studia, 1 (Grottaferrata, 2007).

Congar, Y.M.J., "Quod omnes tangit, ab omnibus tractari et approbari debet," in Revue historique de froit français et étranger 35 (1958), 210-259.

Cygler, F., Das Generalkapitel im hohen Mittelalter. Cisterzienser, Prämonstratenser, Kartäuser und Cluniazenser (Münster, 2001).

Cygler, F., "Le rayonnement des constitutions dominicaines au XIIIe siècle: quelques brèves observations," in M. Breitenstein, J. Burkhardt, S. Burkhardt, and J. Röhrkasten (eds.), Rules and Observance: Devising Forms of Communal Life (Münster, 2014), 239-250.

Cygler, F., "Les chanoines réguliers et le chapitre général (XıIe-début XıIIe siècle)," in M. Parisse (ed.), Les chanoines réguliers: émergence et expansion (XIe-XIIIe siècles); 
actes du sixième colloque international du CERCOR, Le Puy en Velay, 29juin-1er juillet 2006 (Saint-Étienne, 2009), 265-296.

Cygler, F., "Pour une approche comparee des normes et de l'organisation de la vie reguliere au moyen âge: Quelques pistes," in G. Melville and A. Müller (eds.), Mittelalterliche Orden und Klöster im Vergleich: Methodische Ansätze und Perspektiven (Berlin, 2007), 163-186.

Dalarun, J., François d'Assise ou le pouvoir en question. Principes et modalité du gouvernement dans l'Ordre des frères mineurs (Brussels, 1999).

Dalarun, J., Gouverner c'est servir: essai de démocratie médiévale (Paris, 2012).

Desbonnets, T., Dalla intuizione alla istituzione. I francescani (Milan, 1986).

Etzi, P., Iuridica franciscana. Percorsi monografici di storia della legislazione dei tre Ordini francescani (Padua, 2005).

Eubel, C. (ed.), Provinciale Ordinis Fratrum Minorum vetustissimum Secundum Codicem Vaticanum Nr. 1960 (Florence, 1892).

Evangelisti, P., I Francescani e la costruzione di uno stato. Linguaggi politici, valori identitari, progetti di governo in area catalano-aragonese (Padua, 2006).

Evangelisti, P., "Per uno studio della testualità politica francescana tra XIII e XV secolo. Autori e tipologua delle fonti," in Studi medievali 3rd ser. 37 (1996), 549-623.

Evangelisti, P., “'Quis enim conservat civitatem, status et regimina?'. II linguaggio politico e la pedagogia civile di Giacomo della Marca," in F. Serpico (ed.), Gemma Lucens: Giacomo della Marca tra devozione e santità: atti dei convegni, Napoli, 20 novembre 2009, Monteprandone, 27 novembre 2010 (Florence, 2013), 153-173.

Freeman, E., "What makes a monastic order? Issues of methodology in "The Cistercian Evolution," in Cistercian Studies Quarterly 37 (2002), 429-442.

Galbraith, G., The Constitution of the Dominican Order: 1216 to 1360 (Manchester, 1925).

Gaudemet, J. (ed.), Les élections dans l'Église latine des origines au xvie siècle (Paris, 1979).

Golubovich, G., "Le province dell'Ordine minoritico nei secoli XIII e XIV in Europa e nell'Oriente francescano," in Bio-bibliografica della Terra Santa e dell'Oriente francescano, vol. 2 (Florence, 1913), 214-274.

Grélois, A., "Tradition and Transmission: What is the Significance of the Cistercian General Chapters' Statutes? (Twelfth to Fourteenth Centuries)," in K. Pansters and A.G. Plunkett-Latimer (eds.), Shaping Stability: The Normation and Formation of Religious Life in the Middle Ages (Turnhout, 2016), 205-216.

Hoffmann, C. The Cistercian Evolution: The Invention of a Religious Order in TwelfthCentury Europe (Philadelphia, 2000).

Lagarde, G. de, La naissance de l'Esprit lä̈que au déclin du Moyen Age (Louvain, 1934-1963).

Lagarde, G. de, "L'idée de la Représentation dans les Oeuvres de Guillaume d'Ockham," Bulletin of the International Committee of Historical Sciences 9 (1937), 425-451. 
Leclerc, V., "Des Assemblées générales des ordres religieux au Xıı Ie siècle," in L'Institut. Journal universel des sciences et des sociétés savantes en France et a l'étranger. IIe section: Sciences Historiques, Archéologiques et Philosophiques 157 (1849), 3-7.

Lee, H-Y., Political Representation in the Later Middle Ages: Marsilius in Context (New York, 2008).

Mapelli, F.J., L'amministrazione francescana di Inghilterra e Francia. Personale di governo e strutture dell'Ordine fina al Concilio di Vienne (1311) (Rome, 2003).

Menestò E. and S. Brufani (eds.), Fontes Franciscani, Testi, 2 (Assisi, 1995).

Monahan, A., Consent, Coercion, and Limit: The Medieval Origins of Parliamentary Democracy (Leiden, 1987).

Moorman, J.R.H., Medieval Franciscan Houses (Saint Bonaventure, 1983).

Moulin, L., "La science politique et le gouvernement des communautés religieuses," in Revue Internationale des Sciences Administratives 1 (1951), 42-67.

Moulin, L., "Le gouvernement des communautés religieuses comme type de gouvernement mixte," in Revue Française de Science Politique 2, no. 2 (1952), 335-355.

Moulin, L., "Les origines religieuses des techniques électorales et délibératives modernes," in Revue Internationale d'Histoire Politique et Institutionnelle n.s. 3 (1953), 106148; re-issued in Politix 11, no. 43 (1998), 117-162.

Moulin, L., "Une source méconnue de la philosophie politique marsilienne: L'organisation constitutionelle des ordres religieux," in Revue Française de Science Politique 33, no. 1 (1983), 5-13.

Musco, M. (ed.), I Francescani e la politica. Atti del Convegno internazionale di studio Palermo 3-7 Dicembre 2002, 2 vols. (Palermo, 2007).

Nederman, C.J., Community and Consent: the Secular Political Theory of Marsiglio of Padua's Defensor Pacis (Lanham, 1995).

Neukirchen, M. a, De Capitulo generali in primo Ordine seraphico, $\mathrm{PhD}$ Thesis (Rome, 1952).

Oakley, F., The Watershed of Modern Politics: Law, Virtue, Kingship, and Consent (13001650) (New Haven, 2015).

Pennington, K., "Representation in Medieval Canon Law," in The Jurist 64 (2004), 361-383.

Quillet,J., "Community, Counsel and Representation," in J.H. Burns (ed.), The Cambridge History of Medieval Political Thought, c. 350-c. 1450 (Cambridge, Eng., 1988), 520-571.

Stasavage, D., "Representation and Consent: Why They Arose in Europe and Not Elsewhere," in Annual Review of Political Science 19 (2016), 145-162.

Stawski, J., Le principe de la majorité (son histoire, son fondement et les limites de son applications. Études sur la formation de la volonté de Genève (Geneva, 1920).

Sykes, K., "Cistercian influences on Gilbertine legislation," in Citeaux 59 (2008), 209-235. 
Tierney, B., Foundations of the Conciliar Theory: The Contribution of the Medieval Canonists from Gratian to the Great Schism (Cambridge, Eng., 1956).

Tierney, B., "The Idea of Representation in the Medieval Councils of the West," in Concilium 187 (1983), 25-30.

Todeschini, G., 'Le 'bien commun' de la civitas christiana dans la tradition textuelle franciscaine (xıIIe-Xve siècle)," in H. Bresc, G. Dagher and C. Veauvy (eds.), Politique et religion en Méditerranée. Moyen Âge et époque contemporaine (Paris, 2008), 265304 .

Tugwell, S., "The evolution of dominican structures of government," in Archivum Fratrum Praedicatorum 69 (1999), 5-60; 70 (2000), 111-242; 71 (2001), 5-182; 72 (2002), 26159; 75 (2005), 29-79.

Vauchez, A., "Une campagne de pacification en Lombardie autour de 1233. L'action politique des Ordres mendiants d'après la réforme des statuts communaux et les accords de paix," in Mélanges d'archéologie et d'histoire 78 (1966), 503-549.

Waddell, C. (ed.), Twelfth-Century Statutes from the Cistercian General Chapter: Latin Text With English Notes and Commentary (Cîteaux, 2002). 